DOI:

UDC 504.064.4:66.097

B.P. Sereda ${ }^{1}$, Doctor of Tech. Sci., Prof.

K.V. Belokon ${ }^{2}$, Cand. Tech. Sci., Docent

Y.A. Belokon ${ }^{2}$, Cand. Tech. Sci., Docent

D.O. Kruglyak ${ }^{2}$, Cand. Tech. Sci., Docent

D.B. Sereda ${ }^{1}$, Cand. Tech. Sci.

${ }^{1}$ Dniprovsky State Technical University, Kamianske

${ }^{2}$ Zaporizhzhia National University, Zaporizhzhia

\title{
MODEL OF THE MECHANISM REACTION FOR HYDROCARBONS ON INTERMETALLIC CATALYSTS
}

The kinetic characteristics oxidation processes of propane on an intermetallic catalyst of the composition Ni-Co-Mn-Cu-Al are determined. On the basis of the modified model of Mars-Van Crevelin, effective reaction rate constants and activation energies were obtained. For the oxidation of propane on a Ni-Al-Co-Mn-Cu catalyst, the activation energy is $65.5 \mathrm{~kJ} / \mathrm{mol}$, which is 1.2 times lower than the activation energy of $\mathrm{Ni}$-Al alloys.

Keywords: intermetallic catalyst; Mars-Van Crevelen model; reaction rate constant; activation energy

Визначено кінетичні характеристики процесів окислення пропану на інтерметалідному каталізаторі складу Ni-Co-Mn-Cu-Al. На основі модифікованої моделі Марса-Ван Кревель отримані ефективні константи швидкостей реакиій і енергії активації. Для реакиії окислення пропану на каталізаторі складу $\mathrm{Ni}-\mathrm{Al}-\mathrm{Co}-\mathrm{Mn}-\mathrm{Cu}$ енергія активації становить 65,5 кДж/моль, щуо в 1,2 рази нижче енергї активації Ni-Al сплавів.

Ключові слова: інтерметаллідним каталізатор; модель Марса-Ван Кревель; константа швидкості реакиї̈; енергія активаиії

\section{Formulation of the problem}

The study of the mechanism of catalytic reactions of deep oxidation of $\mathrm{C}_{\mathrm{m}} \mathrm{H}_{\mathrm{n}}$ hydrocarbons is complicated by a number of features inherent in this type of reactions. They are highly exothermic, often having a large number of intermediate stages that compete with each other. The deep oxidation on the catalyst proceeds, as a rule, by a parallel mechanism:

$$
\mathrm{C}_{m} \mathrm{H}_{n}+\mathrm{O}_{2} \rightarrow \mathrm{CO}_{2}+\mathrm{H}_{2} \mathrm{O} \text {. }
$$

The hydrocarbon molecule is firmly attached to the catalyst surface and the intermediate reaction products do not fly into the gas phase.

A mechanism may also be implemented whereby a portion of the intermediate products can be desorbed from the surface:

$$
\mathrm{C}_{m} \mathrm{H}_{n}+\mathrm{O}_{2} \rightarrow \mathrm{C}_{m} \mathrm{H}_{n} \mathrm{O}_{y} \rightarrow \mathrm{C}_{m} \mathrm{H}_{n} \mathrm{O}_{y} \rightarrow \mathrm{CO}_{2}+\mathrm{H}_{2} \mathrm{O} .
$$

This mechanism is slower.

These two mechanisms can run in parallel, or in parallel, when one of the intermediates can be fixed on the surface of the catalyst and oxidized thereto to the end.

In deep oxidation, the main mechanism is the interaction of mobile activated oxygen with a fixed carbon complex. The mobile oxygen may be atomic oxygen (for example, $\mathrm{O}^{-}$ions for a number of transition metal oxides) or molecular oxygen (for oxides that do not contain oxygen or easily activated metals in their lattice). In the first case, the reaction is most likely through the carbonatecarboxylate complexes, in the second case through the products of compaction, possibly through carbonyl or peroxide compounds. If there is not enough mobile oxygen in the lattice, these intermediate compounds react with $\mathrm{O}_{2}$ from the gas phase, forming radicals and peroxides that oxidize in the gas phase [1-3]. 


\section{Analysis of recent research and publications}

The idea of adsorption equilibrium and the theory of kinetics of catalytic reactions on the surfaces of catalysts are formulated in the works of M.I. Tymkin, S.Z. Roginsky, S.L. Kiperman [1-3]. The mathematical model [3] of the inhomogeneous surface was proposed as a basis, and it was proposed by M.I. Tomkin, which assumes that the surface has the same number of sections of different varieties, ie uniformly-inhomogeneous surface. It was proved [2] that the experimental activation energies transmit not only the temperature dependence of the rate of the catalysis itself, but also the temperature dependence of the process speed characterizing the changes in the chemical composition of the catalyst. The influence of this factor on the kinetics of heterogeneous catalytic reactions is analyzed in the works of G.K. Boreskova [4], O.Ya. Rozovsky [2].

The kinetic equations of heterogeneous-catalytic processes serve to solve two important questions of catalysis. First, they are the basis for the rational selection of the optimal mode of the catalytic process, and second, the kinetic equations serve to verify the correct understanding of the mechanism of the process.

Therefore, for rational selection of the optimal mode of the catalytic process, additional studies are needed to confirm the correctness of the intended mechanism.

\section{Formulation of the research objective}

The purpose of the work is to establish the regularities of the mechanism of the catalytic reactions of deep oxidation of hydrocarbons on intermetallic Ni-Al catalysts and determine their activation energy.

\section{Statement of the main material}

The mathematical description of the rate of the catalytic process in the form of kinetic equations can be purely empirical, arising only from kinetic measurements or substantiated at the same time by other physicochemical methods. On the basis of the results of such complex studies [5-10], stage diagrams of the process emerge, from which certain kinetic dependences follow.

In developing the mathematical model, the following assumptions were made: the ideal displacement reactor is considered [4]; the reactor is isothermal, that is, temperature gradients in the catalyst layer parallel and perpendicular to the axis of the reactor are absent (equal to 0); catalyst activity is constant.

To ensure the ideal displacement mode during the experiment, the following conditions were fulfilled: the ratio of the length of the catalyst layer to the diameter of the catalyst particles in the layer more than 50; the ratio of the diameter of the reactor to the diameter of the catalyst particles is greater than 10 .

The processes occurring on the catalyst surface can be represented by the following equations:

$$
\begin{aligned}
\mathrm{C}_{m} \mathrm{H}_{n}+\left(m+\frac{n}{4}\right) \mathrm{O}_{2} & =m \mathrm{CO}_{2}+\frac{n}{2} \mathrm{H}_{2} \mathrm{O}, \\
\mathrm{C}_{m} \mathrm{H}_{n}+\left(\frac{m}{2}+\frac{n}{4}\right) \mathrm{O}_{2} & =m \mathrm{CO}+\frac{n}{2} \mathrm{H}_{2} \mathrm{O}, \\
2 \mathrm{CO}+\mathrm{O}_{2} & =2 \mathrm{CO}_{2} .
\end{aligned}
$$

The reactions describe the process of complete oxidation of unburnt hydrocarbons and carbon monoxide.

The reaction of propane oxidation on the catalyst can be described by the following scheme [11]:

$$
\begin{gathered}
\mathrm{O}_{2}+\mathrm{Z} \rightarrow 2 \mathrm{OZ}, \\
\mathrm{C}_{3} \mathrm{H}_{8}+10 \mathrm{OZ} \rightarrow 3 \mathrm{CO}_{2}+4 \mathrm{H}_{2} \mathrm{O}+10 \mathrm{Z},
\end{gathered}
$$

where $Z$ - active catalyst center.

The reaction rate on the catalyst can be written in the form:

$$
W=k\left[C_{3} H_{8}\right]^{\alpha} \cdot\left[\mathrm{O}_{2}\right]^{\beta},
$$

where $\alpha, \beta$ - stoichiometric coefficients indicating how many molecules react; $k$ - velocity constant (constant); $\left[\mathrm{C}_{3} \mathrm{H}_{8}\right],\left[\mathrm{O}_{2}\right]$ - the concentrations of propane and oxygen on the catalyst surface, 
respectively, which can be expressed through the particles of the catalyst surface $\sigma$, occupied by the molecules of these substances.

These particles can be calculated using the Langmuir isotherm [11, 12]:

$$
\begin{gathered}
\sigma_{A}=\frac{b_{A} P_{A}}{1+\sum b_{i} P_{i}}, \\
\sigma_{B}=\frac{b_{B} P_{B}}{1+\sum b_{i} P_{i}},
\end{gathered}
$$

where $\sigma_{A}$ - the degree of filling of the catalyst surface with propane; $\sigma_{B}$ - the degree of filling of the catalyst surface with oxygen; $b_{\mathrm{i}}-$ the adsorption coefficient of the i-th substance; $P_{\mathrm{i}}-$ partial pressure of the $\mathrm{i}$-th substance in the gas phase; $A$ - propane; $B-$ oxygen.

Then the speed of the reaction will take the form:

$$
W=k \cdot \sigma_{A}^{\alpha} \cdot \sigma_{B}^{\beta} .
$$

To facilitate integration, we take $\alpha=\beta=1$, then the reaction rate equation will have the form:

$$
W=k \cdot \frac{b_{A} P_{A} \cdot b_{B} P_{B}}{\left(1+b_{i} P_{i}\right)^{2}}
$$

On the other hand, the reaction rate for substance $A$ in the ideal displacement reactor can be defined as [12]:

$$
W=-n_{A}^{0} \frac{d x_{A}}{S \rho d l}
$$

where $n_{A}^{0}$ - molar consumption of the substance $A ; x_{A}$ - the molar fraction of substance $A$ in the reaction mixture; $S$ - the surface area of the unit of catalyst volume; $\rho$ - bulk density of the catalyst; $l$ - the thickness of the catalyst layer.

Then the equation of the mathematical model is written in the form [11]:

$$
-n_{A}^{0} \frac{d x_{A}}{S \rho d l}=k \cdot \frac{P_{A} \cdot P_{B}}{1+B P_{B}^{2}},
$$

where $P_{A}, P_{B}$ - partial pressures in the mixture of propane and oxygen, respectively; $B-$ coefficient taking into account the effect of adsorption of reagents on the surface.

Since the oxygen content of the mixture decreases approximately in proportion to the decrease in the concentration of propane, the equation of mathematical description will look like:

$$
\begin{aligned}
&-n_{A}^{0} \frac{d x_{A}}{S \rho d l}= k \cdot \frac{x_{A} \cdot \gamma \cdot P}{1+B \cdot x_{A}^{2} \cdot \gamma^{2} \cdot P^{2}}, \\
& \gamma=\frac{x_{B}}{x_{A}},
\end{aligned}
$$

where $\gamma$ - proportionality factor; $x_{A}$ - the molar fraction of substance $A$ in the reaction mixture; $x_{B}$ - the molar fraction of substance $B$ in the reaction mixture.

For the model mixture used $\gamma=0,167[13]$.

Integrating expression (15), we obtain:

By splitting variables:

$$
\int-n_{A}^{0} \frac{d x_{A}}{S \rho d l}=\int k \cdot \frac{x_{A} \cdot \gamma \cdot P}{1+B \cdot x_{A}^{2} \cdot \gamma^{2} \cdot P^{2}}
$$

$$
-n_{A}^{0} \int \frac{1+B \cdot x_{A}^{2} \cdot \gamma^{2} \cdot P^{2} d x_{A}}{x_{A} \cdot \gamma \cdot P}=\int k S \rho d l
$$

Integrating expression (18), we obtain: 


$$
-\frac{n_{A}^{0}}{\gamma \cdot P} \ln \left|x_{A}\right|+B \gamma \cdot P \frac{x_{A}}{2}=k S \rho l+C .
$$

For the convenience of calculation, an effective reaction rate constant was used:

$$
K_{e f f}=k S \rho l \text {. }
$$

Arbitrary continuous integration was sought under initial conditions:

$$
\tau=0 ; l=0 ; x_{A}=x_{A_{\text {наu }}} \text {. }
$$

In order to calculate the mathematical model, experimental studies were carried out at different temperatures. The study of the kinetics of deep oxidation reactions was performed on a flowtype installation. The reactor, with a catalyst sample $\left(1 \mathrm{~cm}^{3}, 0.1-0.3 \mathrm{~mm}\right.$ fraction) installed in it, was purged with low-interest model gas mixture at a fixed temperature. The kinetics of propane combustion was investigated in the temperature range of $225-300{ }^{\circ} \mathrm{C}$ in $25{ }^{\circ} \mathrm{C}$ increments. The gas flow rate varied from 500 to $2000 \mathrm{ml} / \mathrm{min}$. Gas pressure was measured by a pressure gauge, gas consumption by a gas meter [14].

Based on the experimental data obtained, equations (19) were used to calculate the effective reaction rate constant and the coefficient $B$. The results were processed using mathematical statistics methods..

Arrhenius equation was used to determine the reaction rate versus temperature:

$$
K_{\text {eff }}=k_{0} e^{-\frac{E}{R T}}
$$

where $k_{0}$ - the constant value, the so-called pre-exponential factor, in the first approximation is independent of temperature; $E$ - activation energy.

According to the found value of the effective reaction rate constant using the equation of the dependence of the rate constant on the temperature, a kinetic curve was constructed (Fig. 1) by which the activation energy of the propane oxidation reaction on a leached intermetallic catalyst was determined [15].

As a result of the approximation of the data model solution for solving the equation, the dependences for calculating the reaction rate of propane oxidation reaction on intermetallic catalysts of different composition were determined.

The dependences of the effective reaction rate constant and the activation energy value for the systems under test are as follows:

- for the Ni-Al system: $k_{e f f}=0,1384 \cdot e^{-\frac{9476,1}{T}}, E=78,8 \mathrm{~kJ} / \mathrm{mol}$;

- for the Ni-Al-Co system: $k_{\text {eff }}=0,078 \cdot e^{-\frac{9011,5}{T}}, E=74,9 \mathrm{~kJ} / \mathrm{mol}$;

- for the Ni-Al-Co-Mn system: $k_{\text {eff }}=0,0499 \cdot e^{-\frac{8515,8}{T}}, E=70,8 \mathrm{~kJ} / \mathrm{mol}$;

- for the Ni-Al-Co-Mn-Cu system: $k_{\text {eff }}=0,02 \cdot e^{-\frac{7885,1}{T}}, E=65,5 \mathrm{~kJ} / \mathrm{mol}$.

The activation energy of the propane oxidation process on the Ni-Al-Co-Mn-Cu catalyst is less than 1.2 times that on the Ni-Al catalysts of the system, that is, the rate of propane oxidation on the proposed multicomponent catalyst is higher than on the catalysts based on Ni-Al alloys. 

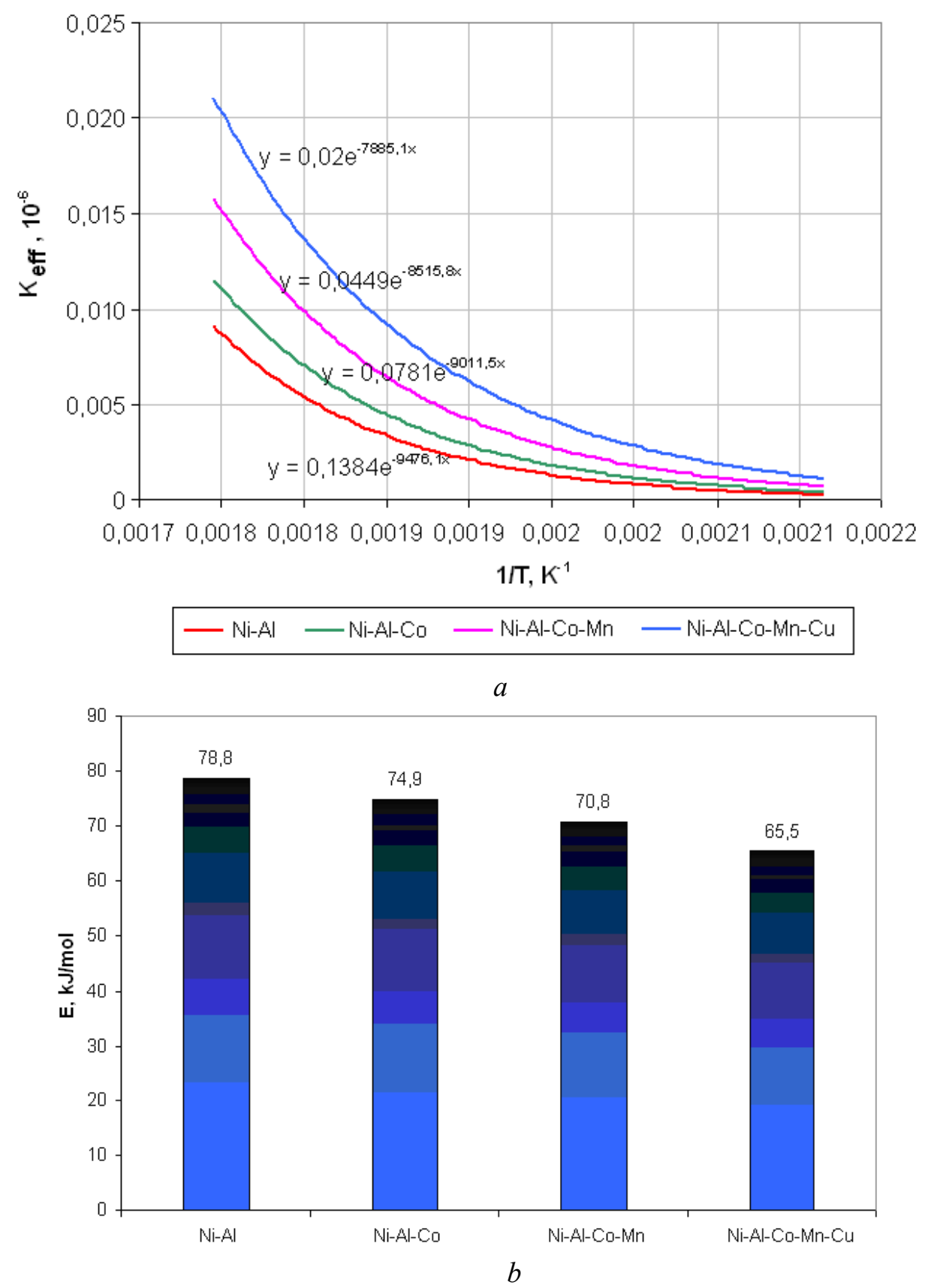

Fig. 1. Investigation of the kinetics of propane oxidation: $a$ - dependence of the effective rate constant of the reaction of propane oxidation on temperature; $b$ - the value of the activation energy.

\section{Conclusions}

The kinetic characteristics of propane oxidation processes on the intermetallic catalyst of Ni$\mathrm{Co}-\mathrm{Mn}-\mathrm{Cu}-\mathrm{Al}$ composition were determined. Based on the modified Mars - Van Crevelen model, effective constants of the reaction rates and the activation energy are obtained. For the reaction of propane oxidation on the catalyst composition of Ni-Al-Co-Mn-Cu activation energy is $65.5 \mathrm{~kJ} / \mathrm{mol}$, which is 1.2 times lower than the activation energy of Ni-Al alloys. Thus, the developed multicomponent catalyst has a lower effective activation energy of reactions, and therefore, it more effectively oxidizes hydrocarbons. 


\section{References}

[1] Temkin M.I. Voprosy himicheskoj kinetiki, kataliza i reakcionnoj sposobnosti [Questions of chemical kinetics, catalysis and reactivity], Moscow: Izd-vo AN SSSR, 1955, 484 p. (in Russian).

[2] Rozovsky A.Y. Kinetika topohimicheskih reakcij [Kinetics of topochemical reactions], Moscow: Himiya, 1974, 224 p. (in Russian).

[3] Kiperman S.L. Osnovy himicheskoj kinetiki v geterogennom katalize [Fundamentals of chemical kinetics in heterogeneous catalysis], Moscow: Nauka, 1979, 359 p. (in Russian).

[4] Boreskov G.K. Kataliz. Voprosy teorii i praktiki [Catalysis. Questions of theory and practice], Novosibirsk: Nauka, 1987, 540 p. (in Russian).

[5] Sereda B., Sereda D., Belokon Y. Modeling deformation in material processing and laws of phasic by SHS pressing intermetallics alloys. Materials Science and Technology. 2015. Vol. 1. P. 611-617.

[6] Grigoryan E.A., Merzhanov A.G. Katalizatory XXI veka [Catalysts of the XXI century]. Nauka proizvodstvu, 1998, no. 3 (5), pp. 30-41 (in Russian).

[7] Belokon K., Belokon Y. The study of catalysts based on intermetallic NiAl alloys. Ceramic Transactions. 2018. Vol. 262. P. 219-225.

[8] Sereda B., Belokon' Y., Zherebtsov A., Sereda D. The Researching and modeling of physicalchemical properties of Ni-base alloys in SHS conditions. Materials Science and Technology. 2012. Vol.1. P. 494-498.

[9] Belokon K., Belokon Y. The usage of heat explosion to synthesize intermetallic compounds and alloys. Ceramic Transactions. 2018. Vol. 261. P. 109-115.

[10] Sereda B., Sheyko S., Kruglyak I., Belokon' Y. Application of activation of substrate by aluminium and copper for increase of adhesive durability of sheetings received in selfpropagating high-temperature synthesis conditions. 10th International Conference on the Science and Technology of Adhesion and Adhesives. Oxford, UK. 2008. P. 437-439.

[11] Krylov O.V. O mekhanizme glubokogo kataliticheskogo okisleniya uglevodorodov [On the mechanism of deep catalytic oxidation of hydrocarbons], Deep catalytic oxidation of hydrocarbons. Problems of kinetics and catalysis. 1981, Vol. 18, pp. 5-13. (in Russian).

[12] Belokon Y., Zherebtsov A., Belokon K. The investigation of physical-mechanical properties of intermetallic Ni-Al catalyst with nanostructure. IEEE International Young Scientists Forum on Applied Physics and Engineering (YSF-2017). (Lviv, October 17-20, 2017). Lviv, 2017. P. 299302.

[13] Snagovsky Y.S. and Ostrovsky G.M. Modelirovanie kinetiki geterogennyh kataliticheskih processov [Modeling of kinetics of heterogeneous catalytic processes], Moscow: Himiya, 1976, 248 p. (in Russian).

[14] Belokon K.V., Belokon Y.A., Kozhemyakin G.B., Matukhno E.V. Environmental assessment of the intermetallic catalysts utilization efficiency for deactivation of the pollutants emitted by electrode production enterprises. Scientific bulletin of National Mining University. № 3 (153). 2016. P. 87-94.

[15] Belokon Y., Zherebtsov A., Belokon K. The investigation of nanostructure formation in intermetallic $\gamma$-TiAl alloys. IEEE International Young Scientists Forum on Applied Physics and Engineering (YSF-2017). (Lviv, October 17-20, 2017). Lviv, 2017. P. 311-314. 


\section{МОДЕЛЬ МЕХАНІЗМНОЇ РЕАКЦІЇ ГІДРОКАРБОНІВ НА МЕЖМЕТЕТАЛІЧНИХ КАТАЛІСТАХ

\author{
Середа Б.П., Бєлоконь Ю.О., Бєлоконь К.В., Кругляк Д.О., Середа Д.Б.
}

\section{Реферат}

Вивчення механізму каталітичних реакцій глибокого окислення вуглеводнів $C_{m} H_{n}$ ускладнено рядом особливостей, властивих цьому виду реакцій. Вони високоекзотермічні, часто мають велике число проміжних стадій, що конкурують між собою. Ці два механізми можуть проходити паралельно, або паралельно-послідовно, коли один 3 проміжних продуктів може закріплюватися на поверхні каталізатора і окислюватися на ньому до кінця.

Математичний опис швидкості каталітичного процесу у вигляді кінетичних рівнянь може бути чисто емпіричним, що випливають тільки 3 кінетичних вимірювань або обгрунтованим одночасно й іншими фізико-хімічними методами. На основі результатів таких комплексних досліджень виникають стадійні схеми процесу, з яких випливають певні кінетичні залежності.

Для розрахунку математичної моделі були проведені експериментальні дослідження при різних температурах. Дослідження кінетики реакцій глибокого окислення проводилося на установці проточного типу. Реактор, з встановленим в ньому зразком каталізатора $\left(1 \mathrm{~cm}^{3}\right.$, фракція 0,1-0,3 мм), продувався низькопроцентних модельної газовою сумішшю при фіксованому значенні температури. Кінетика горіння пропану досліджувалася в інтервалі температур $225-300{ }^{\circ} \mathrm{C}$ з кроком $25{ }^{\circ} \mathrm{C}$. Витрата газу змінювався в межах від 500 до 2000 мл/хв. Тиск газу вимірювалося манометром, витрата газу - газовим лічильником. За знайденим значенням ефективної константи швидкості реакції з використанням рівняння залежності константи швидкості від температури була побудована кінетична крива за допомогою якої були визначені і енергія активації реакції окислення пропану на вилуженому інтерметалідному каталізаторі.

Визначено кінетичні характеристики процесів окислення пропану на інтерметалідному каталізаторі складу Ni-Co-Mn-Cu-Al. На основі модифікованої моделі Марса-Ван Кревель отримані ефективні константи швидкостей реакцій і енергії активації. Для реакції окислення пропану на каталізаторі складу Ni-Al-Co-Mn-Cu енергія активації становить 65,5 кДж/моль, що в 1,2 рази нижче енергії активації $\mathrm{Ni}-\mathrm{Al}$ сплавів.

\section{Література}

1. Тёмкин М.И. Вопросы химической кинетики, катализа и реакционной способности. М.: Изд-во АНСССР, 1955. $484 \mathrm{c.}$

2. Розовский А.Я. Кинетика топохимических реакций. М.: Химия, 1974. 224 с.

3. Киперман С.Л. Основы химической кинетики в гетерогенном катализе. М.: Наука, 1979. 359 c.

4. Боресков Г.К. Катализ. Вопросы теории и практики. Новосибирск: Наука, 1987. 540 с.

5. Sereda B., Sereda D., Belokon Y. Modeling deformation in material processing and laws of phasic by SHS pressing intermetallics alloys. Materials Science and Technology. 2015. Vol. 1. P. 611617.

6. Григорян Э. А., Мержанов А. Г. Катализаторы XXI века. Наука производству. 1998. №3 (5). C. $30-41$.

7. Belokon K., Belokon Y. The study of catalysts based on intermetallic NiAl alloys. Ceramic Transactions. 2018. Vol. 262. P. 219-225.

8. Sereda B., Belokon' Y., Zherebtsov A., Sereda D. The Researching and modeling of physicalchemical properties of Ni-base alloys in SHS conditions. Materials Science and Technology. 2012. Vol.1. P. 494-498.

9. Belokon K., Belokon Y. The usage of heat explosion to synthesize intermetallic compounds and alloys. Ceramic Transactions. 2018. Vol. 261. P. 109-115.

10. Sereda B., Sheyko S., Kruglyak I., Belokon' Y. Application of activation of substrate by aluminium and copper for increase of adhesive durability of sheetings received in self-propagating 
high-temperature synthesis conditions. 10th International Conference on the Science and Technology of Adhesion and Adhesives. Oxford, UK. 2008. P. 437-439.

11. Крылов О.В. О механизме глубокого каталитического окисления углеводородов. Глубокое каталитическое окисление углеводородов. Проблемы кинетики и катализа. М.: Наука, 1981. Вып. 18. С. 5-13.

12. Belokon Y., Zherebtsov A., Belokon K. The investigation of physical-mechanical properties of intermetallic Ni-Al catalyst with nanostructure. IEEE International Young Scientists Forum on Applied Physics and Engineering (YSF-2017). (Lviv, October 17-20, 2017). Lviv, 2017. P. 299302.

13. Снаговский Ю.С., Островский Г.М. Моделирование кинетики гетерогенных каталитических процессов. М.: Химия, 1976. 248 с.

14. Belokon K.V., Belokon Y.A., Kozhemyakin G.B., Matukhno E.V. Environmental assessment of the intermetallic catalysts utilization efficiency for deactivation of the pollutants emitted by electrode production enterprises. Scientific bulletin of National Mining University. № 3 (153). 2016. P. 87-94.

15. Belokon Y., Zherebtsov A., Belokon K. The investigation of nanostructure formation in intermetallic r-TiAl alloys. IEEE International Young Scientists Forum on Applied Physics and Engineering (YSF-2017). (Lviv, October 17-20, 2017). Lviv, 2017. P. 311-314. 